\title{
CASE STUDY: 20 YEARS OF ACID ROCK DRAINAGE CHEMISTRY IMPROVEMENTS AFTER A BACTERICIDE APPLICATION ${ }^{1}$
}

\author{
James J. Gusek ${ }^{2}$ and Van G. Plocus
}

\begin{abstract}
The Fisher site is a backfilled and reclaimed (in 1984) surface coal mine in western Pennsylvania, USA. A post-closure toe seep at the site discharged acid rock drainage generated in pyritic rock zones that were identified using geophysical techniques. In 1995, sodium hydroxide and bactericide solutions were injected through cased boreholes into the pyritic zones in a two-step process: sodium hydroxide followed by bactericide. Prior to the event, the toe seepage had been treated with the addition of sodium hydroxide followed by a series of settling ponds and wetland zones. Post-injection, the seepage exhibited net-alkaline chemistry and the sodium hydroxide amendment was discontinued. Based on the prevailing wisdom at the time, the effects of the injection event were expected to be temporary. Two decades later, the beneficial effects of the two-step injection event appear to persist and bond release for the site is pending. The seep chemistry has been monitored for over 25 years and the data trends suggest that the steady-state condition of net alkalinity in the seep water entering the ponds and wetland may be permanent. One current view is that the initial suppression of Acidithiobacillus ferrooxidans bacterial community with the sodium hydroxide and bactericide has been maintained by the seasonal infusion of anti-bactericidal organic acids derived from the robust vegetative cover. The situation appears to be self-sustaining. Others may view the data skeptically; that is, the cause and effect of bactericide application and the sustained benefits of the vegetative cover are not proven conclusively. Certainly, the observations suggest that additional focused study is warranted.
\end{abstract}

Additional Key Words: sustainability, surfactant, coal, ARD, probiotics

1 Paper presented at the 2015 National Meeting of the American Society of Mining and Reclamation, Lexington, KY Reclamation Opportunities for a Sustainable Future June 7 - 11, 2015. R.I. Barnhisel (Ed.) Published by ASMR, 1305 Weathervane Drive, Champaign, IL 61821.

${ }^{2}$ James J. Gusek, P.E. is a senior engineer with Sovereign Consulting Inc., Lakewood, CO; Van G. Plocus, P.E. is the president of Diamond Engineering, Blairsville, PA.

Journal American Society of Mining and Reclamation, 2016 Volume 5, Issue 1 pp 67 - 85

DOI: http://doi.org/10.21000/JASMR16010067 


\section{Introduction}

Worldwide, reclaimed/revegetated mine sites (both coal and hard rock) continue to experience significant acid rock drainage (ARD) problems. The sites represent a perpetual treatment problem for the mine operator, contribute to environmental degradation of surface water and groundwater resources, and may prevent bond release. Conventional and passive treatment methods typically treat the symptoms of ARD, not its source. As evidenced by ARD being discharged from mines that were operated by the Romans over two thousand years ago, ARD can persist for millennia (Bayona et al., 2013). Considering the one billion tonnes of acid-prone waste rock and tailings that are generated annually in the USA (NCBI, 2001), a commitment to perpetual treatment is clearly not sustainable. ARD source control is clearly the "pathway to walk away," but the mining industry seems to be reluctant to embrace unproven technologies. The recurring question is: "show us the data." Even when data are available, sampling protocols (if they are ever documented) can change over time, data gaps may occur for no reason, and even the sampling points can shift. This is the situation for this particular case history; the data set is not robust but the authors believe it is complete enough to be useful.

The iron-oxidizing bacteria, Acidithiobacillus ferrooxidans $(A T B F O)$, have proven to play a critical role in creating ARD and are strongly associated with the formation of acid mine drainage (Kleinmann et al., 1980; Schrenk et al., 1998). Metals found in mine soils, including Fe, Mn, Al, $\mathrm{Mg}, \mathrm{Pb}, \mathrm{Cu}, \mathrm{Zn}, \mathrm{Cd}$, and $\mathrm{Se}$ are solubilized, creating drainage that is toxic to the environment. Suppression of $A T B F O$ has proven to significantly reduce the generation of ARD at mine sites (Rastogi, 1996; Verburg, 2003).

\section{Bactericide Usage History}

Anionic surfactants are effective inhibitors of $A T B F O$, as they destroy the integrity of the cytoplasmic membrane of the bacteria thus allowing the acid that they create to enter the cells and destroy them (Kleinmann and Erikson, 1983). Their use was first promoted in the late 1970's and was successfully applied in the early 1980's (Kleinmann, 1979; Kleinmann and Erikson, 1983). However, skeptics in the mining community and mining regulators have argued (and rightfully so), that the inhibitory effects of anionic surfactants are temporary, as these highly soluble reagents can be rinsed from the treated mine wastes and $A T B F O$ communities can rebound (Robertson and Barton-Bridges, no date; Caruccio and Geidel, 1986). Verburg reported that “...the longevity of 
the bactericide in the experimental setting is unknown, but it appears to be effective throughout the 30-week period. Under operational or post-closure conditions, periodic or continuous application of a surfactant-type bactericide is generally required to maintain effectiveness" (Verburg, 2003). To address this problem, commercial slow-release anionic surfactants such as ProMac $^{\mathrm{TM}}$ were developed in the late 1980's (Rastogi, 1996; Kleinmann and Erikson, 1983). But the mining community and regulators were not convinced, and demonstrated long-term effectiveness of bactericide applications was lacking.

Fortunately, anionic surfactants are not the only ATBFO inhibitors. Thirty-five years ago, Pichtel and Dick (1990) found that the following materials, some considered waste by modern society, can suppress ARD:

- Composted sewage sludge (biosolids),

- Composted paper mill sludge,

- Pyruvic acid (an organic acid), and

- A water-soluble extract from composted sewage sludge.

The ARD inhibitory effects of organic acids were cited by Sobek et al. (1990) as an important component in the long term (i.e., greater than three years) success of anionic surfactant usage. An excerpt from this paper follows.

Control of acid generation for prolonged periods greatly enhances reclamation efforts and can reduce reclamation costs by reducing the amount of topsoil needed to establish vegetation. Three natural processes resulting from strong vegetative cover for three years or more can break the acid production cycle. These processes are:

- A healthy root system that competes for both oxygen and moisture with acid-producing bacteria;

- Populations of beneficial heterotrophic soil bacteria and fungi that are re-established, resulting in the formation of organic acids that are inhibitory to T. ferrooxidans (Tuttle et al., 1977); and

- The action of plant root respiration and heterotrophic bacteria increase $\mathrm{CO}_{2}$ levels in the spoil, resulting in an unfavorable microenvironment for growth of T. ferrooxidans. 
More recently, researchers at the Wyoming Research Institute (Jin, 2008) determined that a biofilm nurtured by waste milk or other dairy products, inoculated with a "probiotic" bacterial community, could out-compete $A T B F O$ on the surfaces of pyrite grains and thus suppress ARD. Some research (Lundgren, 1971 [page 13]) suggests that the ATBFO community actually switches from a chemotrophic nutrient/energy source (i.e., the pyrite) to a heterotrophic nutrient/energy source when it is confronted with an overabundance of organic matter. Certainly, the presence of organic matter in protein form (e.g., casein) from the dairy source would support a predominantly proteolytic bacterial community that would in turn support sulfate reducers (Seyler et al., 2003). Either way, the oxidation of pyrite by $A T B F O$ is probably suppressed. Again, however, the question remains: what happens when the milk/dairy waste is consumed? Will the ATBFO community recover and dominate the situation?

This issue was addressed two decades ago. Water quality data was gathered from two sites where bactericides had been applied to evaluate the suppression of $A T B F O$ and the potential longevity of bactericidal treatment. The objective was to assess the application methods of bactericide and determine the water quality changes over time from two seeps in the northern Appalachian Basin. A summary of the investigation findings follows.

\section{$\underline{\text { Bacterial Community Shifts }}$}

Two reclaimed mine sites, one near Steubenville, $\mathrm{OH}$ and another near Clarksburg, WV received slow release anionic surfactant treatments in 1984 and 1987, respectively (Rastogi, 1996). Increased vegetative growth was the primary goal of the surfactant applications; ARD suppression was a secondary benefit. The sites were investigated in 1994 and the benefits of the anionic surfactant persisted well beyond the normal longevity of the surfactant itself. However, the vegetative response in the treated portions of the sites was so robust that the ARD seepage was virtually eliminated. The less vegetated control plots still discharged ARD, suggesting that moisture uptake by the vegetation suppressed infiltration. Concurrent investigation results revealed that $A T B F O$ populations in the treated soils were vastly outnumbered by beneficial heterotrophic bacteria by two to three orders of magnitude. It is unknown whether the $A T B F O$ strains observed had "switched" from chemotrophs to heterotrophs at the Steubenville and Clarksburg sites or that Darwinian forces favored the proliferation of heterotrophs once the ATBFO population had been decimated by the bactericide. Either way, ARD suppression appeared to occur. 
Despite the laboratory and overwhelming field evidence, the use of bactericides to suppress ARD was never a commercial success. One reason for this outcome might have been that it was not considered a permanent remedy. A decade of positive performance was apparently not enough. Another contributing reason might have been that the chief proponent of the technology retired and was unable to sell the technology to a successor.

\section{Subsurface Injection of Bactericide}

As of the mid-1990's, anionic surfactants had only been applied to surface sources of ARD. That changed when Plocus and Rastogi (1997) demonstrated that subsurface application of anionic surfactants using injection techniques could successfully reduce ARD at the Fisher coal mine site in Banks Township, Indiana CO, PA. This was accomplished by identifying the acid-generating zones using geophysical techniques and designing a multiple-stage borehole based injection program that targeted the ARD "hot spots."

Geophysical mapping with electromagnetic terrain conductivity meters and magnetometers were utilized to identify pyritic zones which were responsible for the high acid production on the Fisher Site. See Plocus and Rastogi (1997) for a more detailed discussion of the geophysical investigation.

\section{Site Description}

The Fisher Site was a typical reclaimed mine site which continued to generate post-reclamation ARD. The Fisher Site location map and site vicinity map are found in Figs. 1 and 2, respectively. The geophysical investigation area is heavily shaded in Fig. 2.

A single coal seam ( $\sim$ m thick) was mined in the early 1980's using surface mining techniques. Anecdotal information suggested that a high-ash coal containing pyritic shale partings had been buried in the pit during the mining operations. Infiltrating precipitation and contact with groundwater in these zones of concentrated pyritic material resulted in localized ARD production. A resultant ARD plume eventually surfaced as an acidic seep with levels of $\mathrm{Fe}, \mathrm{Mn}$, and $\mathrm{pH}$ exceeding permit effluent limits. Table 1 presents water quality data on the raw ARD seep on the Fisher Site and the associated limits for these parameters. 
JASMR, 2016 Volume 5 Issue 1

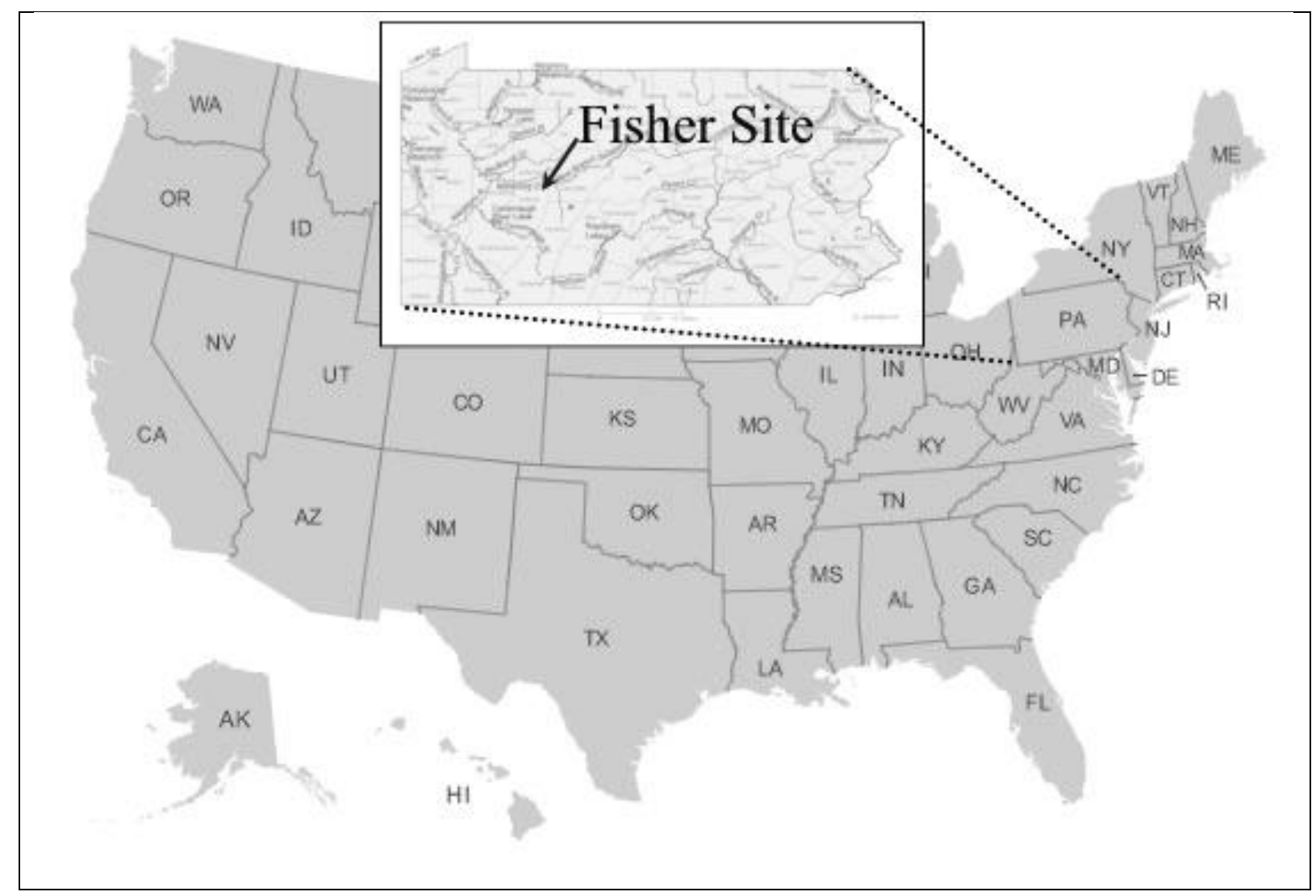

Figure 1. Site Location Map

Table 1 Fisher Site ARD chemistry and regulatory limits

\begin{tabular}{lcccc}
\hline Parameter & $\begin{array}{c}\text { Raw } \\
\text { Seep Value }\end{array}$ & $\begin{array}{c}\text { Pre-Injection } \\
\text { "Bog" Effluent }\end{array}$ & $\begin{array}{c}\text { Regulatory } \\
\text { Limits } \\
\text { (Monthly avg.) }\end{array}$ & $\begin{array}{c}\text { Regulatory } \\
\text { Limits } \\
\text { (Instant. Max.) }\end{array}$ \\
\hline Fe (mg/L) & 8 to 42 & 17.7 & 3.0 & 7.0 \\
Mn (mg/L) & 6 to 12 & 12.4 & 2.0 & 5.0 \\
pH (s.u.) & 5 to 6 & 5.5 & & 6.0 to 9.0 \\
Acidity (mg/L) & $>$ alkalinity & Est. $~ 54$ & n/a & n/a \\
\hline
\end{tabular}




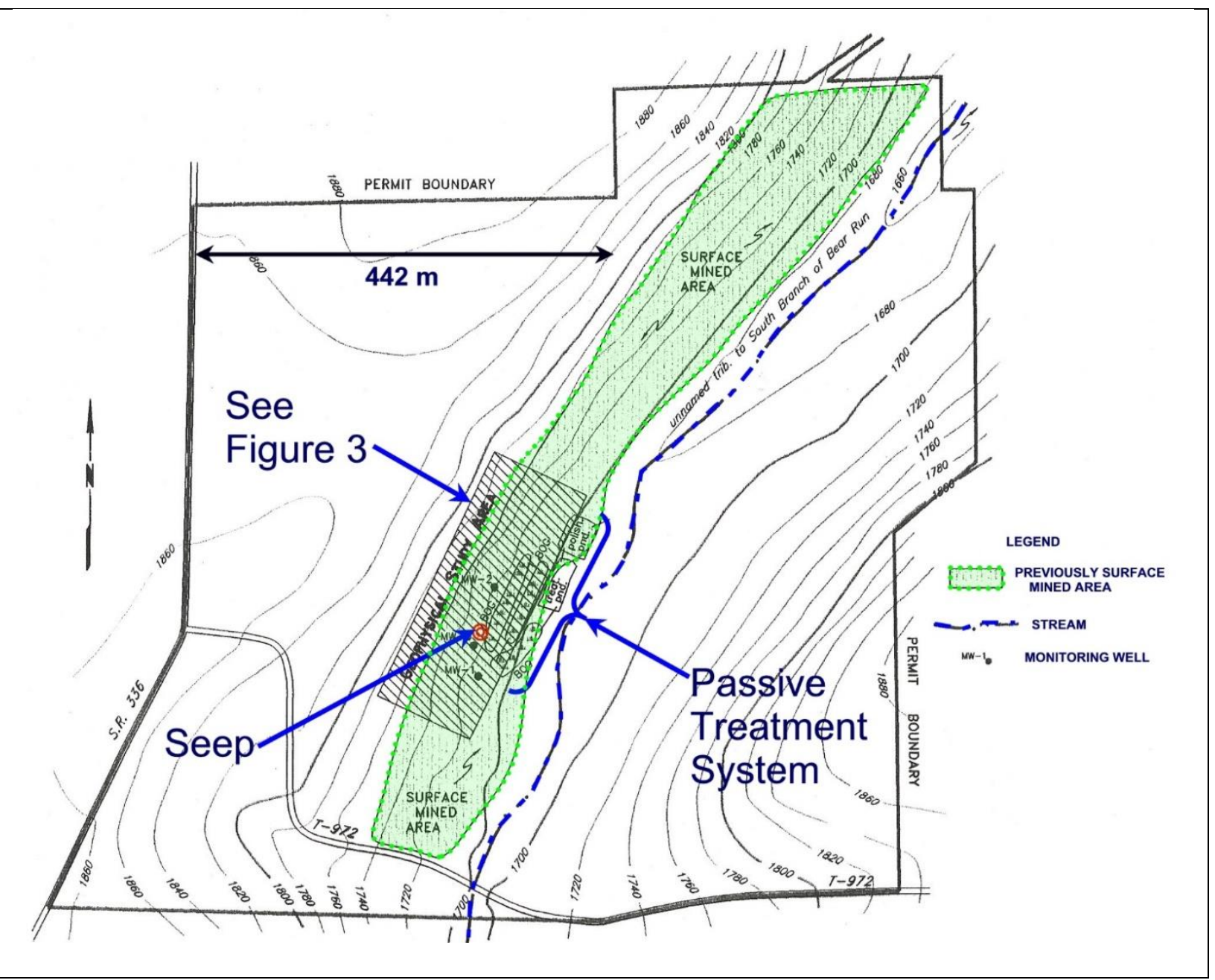

Figure 2. Site vicinity map (After Plocus and Rastogi, 1997).

Site reclamation consisted of pit backfilling and revegetation; this effort was completed in 1984. The effluent from a small (0.25 ha) passive treatment system, constructed in 1985 to manage the raw seepage, did not meet Pennsylvania Department of Environmental Protection (PA DEP) standards. The Surface Mining Permit for Fisher mine stated that alkalinity must exceed acidity at all times (BMR, 1984). To remedy this situation, two treatment ponds were constructed after the passive treatment system; supplementary semi-active treatment with a $\mathrm{NaOH}$ solution comprised the long-term treatment plan for this reclaimed and revegetated surface mine. With the exception of the post-mine discharge which exceeded effluent limits, the Fisher Site had met all requirements established by the PA DEP for bituminous coal extraction and reclamation.

In 1993, the pollution liability of this site was transferred from the coal company to a third party. Because the site effluent met existing regulatory limits using a $\mathrm{NaOH}$ amendment as an 
interim remedy, this site was viewed as an opportunity to evaluate ARD source control alternatives, in particular, the injection of anionic surfactants.

The prevailing theory in 1993 was that the source of ARD on the Fisher Site was similar to other reclaimed sites: it was primarily located in the buried mine spoil. Unfortunately, conventional surface application of anionic surfactants was believed to be ineffective on revegetated sites as it could not penetrate through subsoil, topsoil, and vegetation (Plocus and Rastogi, 1997). In retrospect, drip irrigation delivery of anionic surfactant solution routinely used in heap leaching operations at metal mines may have overcome this perceived limitation. Consequently, an alternative more-invasive and focused surfactant delivery method was needed and injection through multiple boreholes was a logical choice. Injecting surfactant into the entire mine spoil mass was not practical, however. As subsequently determined, neither was it necessary.

Plocus and Rastogi (1997) developed an innovative approach to (1) identify the source of ARD on the Fisher Site using geophysical mapping, (2) install subsurface injection wells, and (3) inject sodium hydroxide and an anionic surfactant into the toxic zones within the subsurface strata of the Fisher Site. Among the many uncertainties at the time was the longevity of the bactericide.

\section{Site Characterization and Geophysical Mapping}

Identification of backfill zones with elevated pyrite concentration was critical in determining the target locations for installation of injection wells. A 3.2-ha portion of the backfilled pit immediately up-gradient of the seep was mapped using data gathered with non-invasive geophysical techniques that included: 1) electromagnetic terrain conductivity meters to determine locations of subsurface aquifers, and 2) proton processing magnetometers to delineate zones of pyritic oxidation in the subsurface environment. Infiltrometers were also used to determine permeability which influences pressure requirements and distance between wells.

Based on the results of geophysical mapping, three primary acid producing zones were suspected; the center of each zone received an exploratory boring and the cuttings were analyzed for acid-base accounting parameters. This effort, coupled with geophysics data interpretation, yielded six target zones for surfactant injection. Three of the most significant target zones were selected for subsurface injection of the anionic surfactant.

\section{Application of Subsurface Injection Techniques}


After the acid-producing areas were delineated, five deep wells (OB-series) were drilled in June 1995 into the acid aquifers for $\mathrm{NaOH}$ injection to neutralize the existing acidic waters, and 29 shallower wells were drilled into the pyritic zones for injection of an anionic surfactant bactericide to prevent future acid generation. During drilling activities, mine spoil samples were collected at one-meter intervals for overburden analysis. The location of injection wells, monitoring wells, passive treatment system (aka "bog"), and treatment ponds are shown in the site layout map in Fig. 3.

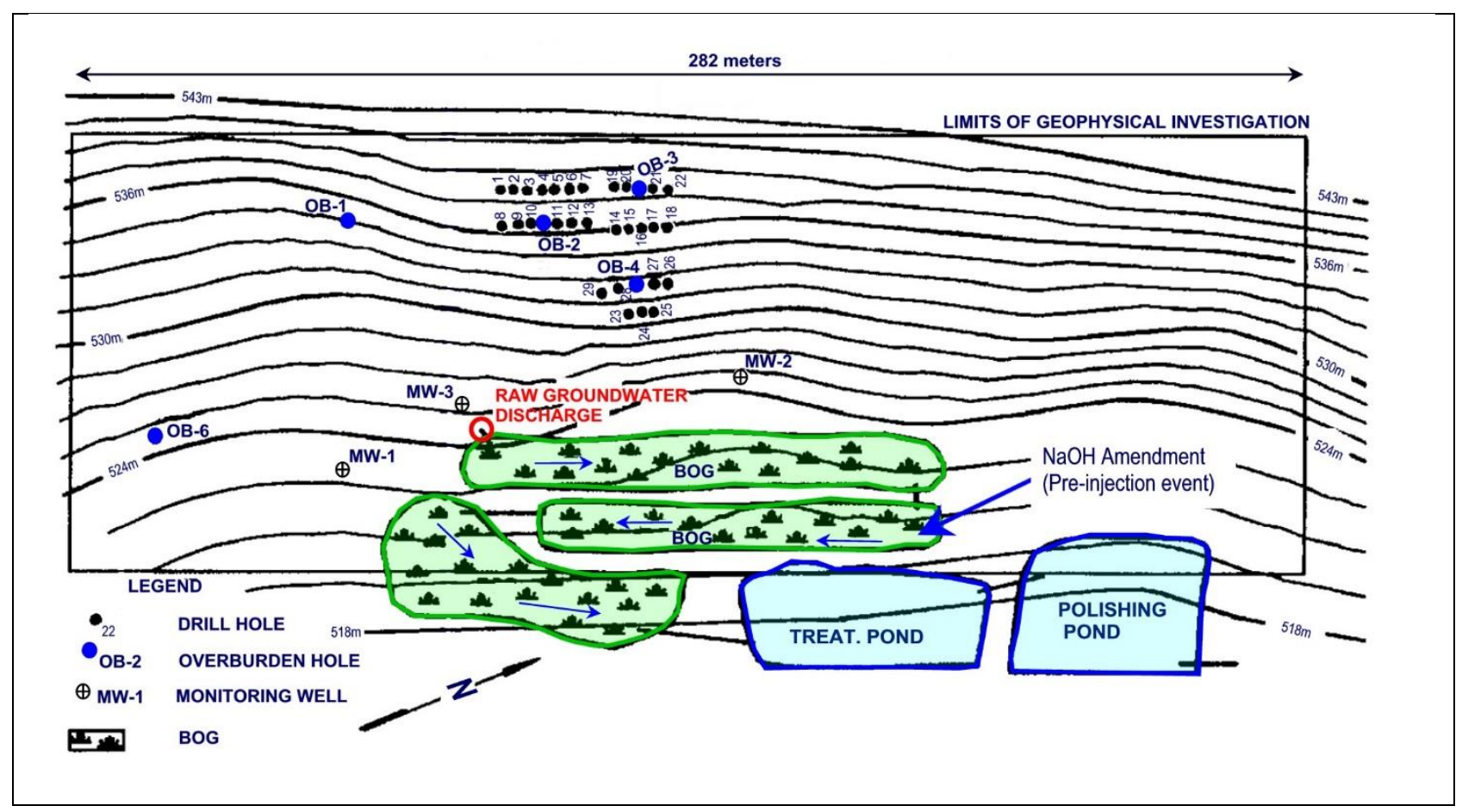

Figure 3. Injection site layout (After Plocus \& Rastogi, 1997).

A series of 29 shallow drill holes $(35 \mathrm{~mm}$ diameter) were placed at the source of the acid production as indicated by the geophysical data. Grout packers were installed to permit pressure injection control. All deep injection wells (OB-series and MW-series) were cased with 50mm diameter PVC pipe with screened lengths ranging from 1.5 meters (typical) to 3.0 meters. The annular space between the casing and the borehole was sealed with bentonite and concrete. The screens helped in pressurized distribution of the injected caustic soda solution in the deep wells. The depth of the shallow injection wells was approximately three (3) meters while the depth of the monitoring wells and overburden wells averaged 16 meters (37 wells total, shallow and deep). Some of the shallow and deep wells were tightly grouped spatially as shown in Fig. 3. 
Injection of a $20 \%$ solution of $\mathrm{NaOH}$ began in mid-June, 1995 using pumps capable of delivering pressures of 20.7MPa. Each deep injection well received about 1,140 liters of caustic solution. This was followed by injection of about 570 liters of a $2 \%$ solution of the anionic surfactant bactericide into the 29 shallow injection wells. In total, about 33,000 liters of $20 \%$ $\mathrm{NaOH}$ solution and 40,000 liters of $2 \%$ strength surfactant were injected over the span of 30 days. In 1995, the cost of these reagents was about \$US 8,400.

The chemical amendment treatment system already in place at the Fisher Site (Fig. 3) was maintained for a one-month period after the initial injection. By that time, the quality of the raw seep prior to entering the passive treatment system had improved enough that the post-passive treatment chemical amendment addition was discontinued. Eventually, the seep quality itself improved to the point that even the passive treatment system was deemed unnecessary and raw seep water was diverted around it.

\section{$\underline{\text { Results }}$}

The raw groundwater discharge point (Fig. 3) represents the acid seep discharge into the passive treatment system/bog, which historically flowed at an average rate of 190 to 570 liters per minute. Figures 4 through 11 summarize results (loading rates and concentrations) for alkalinity/acidity, $\mathrm{pH}, \mathrm{Fe}, \mathrm{Mn}$, and sulfate for this location, respectively. Rather than focus on instantaneous responses to drought or elevated flows, the discussion that follows will address longterm trends and offer plausible explanations in the context of the suppression of the acidophilic microbial community.

Acidity, Alkalinity, and $\mathrm{pH}$ Prior to subsurface injection, acidity typically exceeded alkalinity on the Fisher Site at the point of raw groundwater discharge, (see Figs. 4 and 5). After subsurface injection of $\mathrm{NaOH}$ and the anionic surfactant, alkalinity has exceeded acidity, and this condition was typically maintained even during and immediately after a prolonged drought. This is a condition necessary for bond release. The raw data is quite scattered due to the effects of drought and other unknown factors. Loading (flow times concentration) estimates are typically used to evaluate the overall effectiveness of a remedy. Figures 4 and 5 indicate a "tipping point" occurred about 13 years after the injection event when negative acidity results produced an even wider spread between acidity and alkalinity loading. The precise reasons for this apparently favorable situation are unclear and the data may have been due to a change in the analytical method. The 
$\mathrm{pH}$ results (Fig. 6) for the same period do not reflect any dramatic improvement, but about a year later a $\mathrm{pH}$ improvement trend is evident and it continues to persist in 2015 . On the average, preinjection acidity loadings were about $7.1 \mathrm{~kg} /$ day; post-injection average acidity loadings were about $1.0 \mathrm{~kg} /$ day and appear to be on a steady, stable (declining) trend, even going negative.

The data in Figs. 4 and 5 suggest that the positive effects of the injection event were quite pronounced in the three years following it. While the magnitude of the effects (the difference between acidity and alkalinity) appeared to abate, the conditions for bond release have been satisfied for the last 20 years. Compare this trend to the $\mathrm{pH}$ data that is plotted in Fig. 6 and the iron and manganese data that are provided in Figs. 7 through 10, respectively.

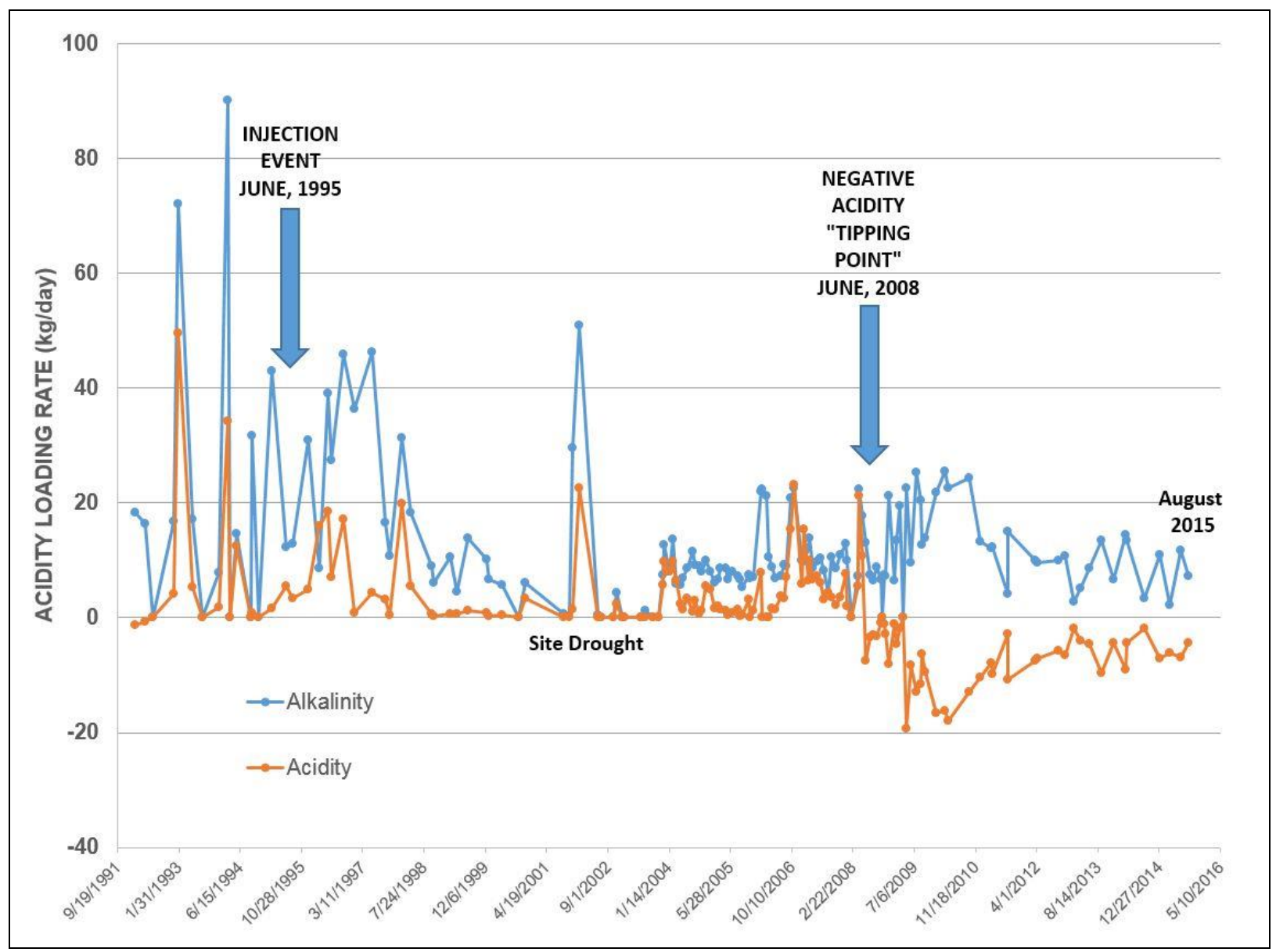

Figure 4. Seep acidity and alkalinity loading 1991 to 2015. 
JASMR, 2016 Volume 5 Issue 1

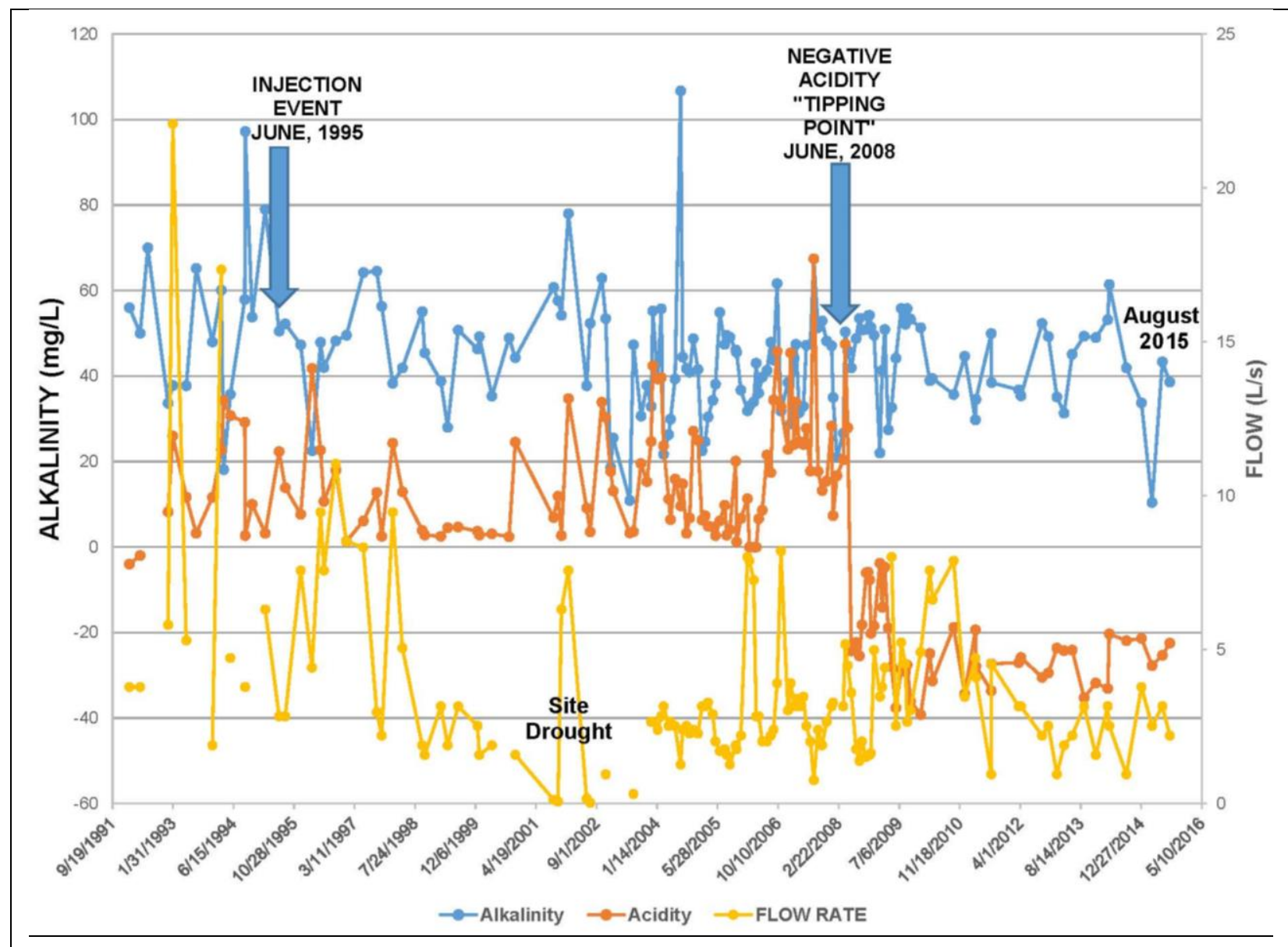

Figure 5. Seep acidity and alkalinity concentration trend 1991 to 2015.

Decreased Sulfate Levels As further evidence of the reduction of acid formation, sulfate concentration in the seep discharge decreased compared to pre-injection event levels. (See Fig. 11.) This decrease, coupled with maintenance of an alkalinity level exceeding acidity levels, indicates the seep water quality is being maintained long after the immediate effects of alkaline injection and bactericide have worn off. The acidophilic community appears to be suppressed by mechanisms that are sustainable. 
JASMR, 2016 Volume 5 Issue 1

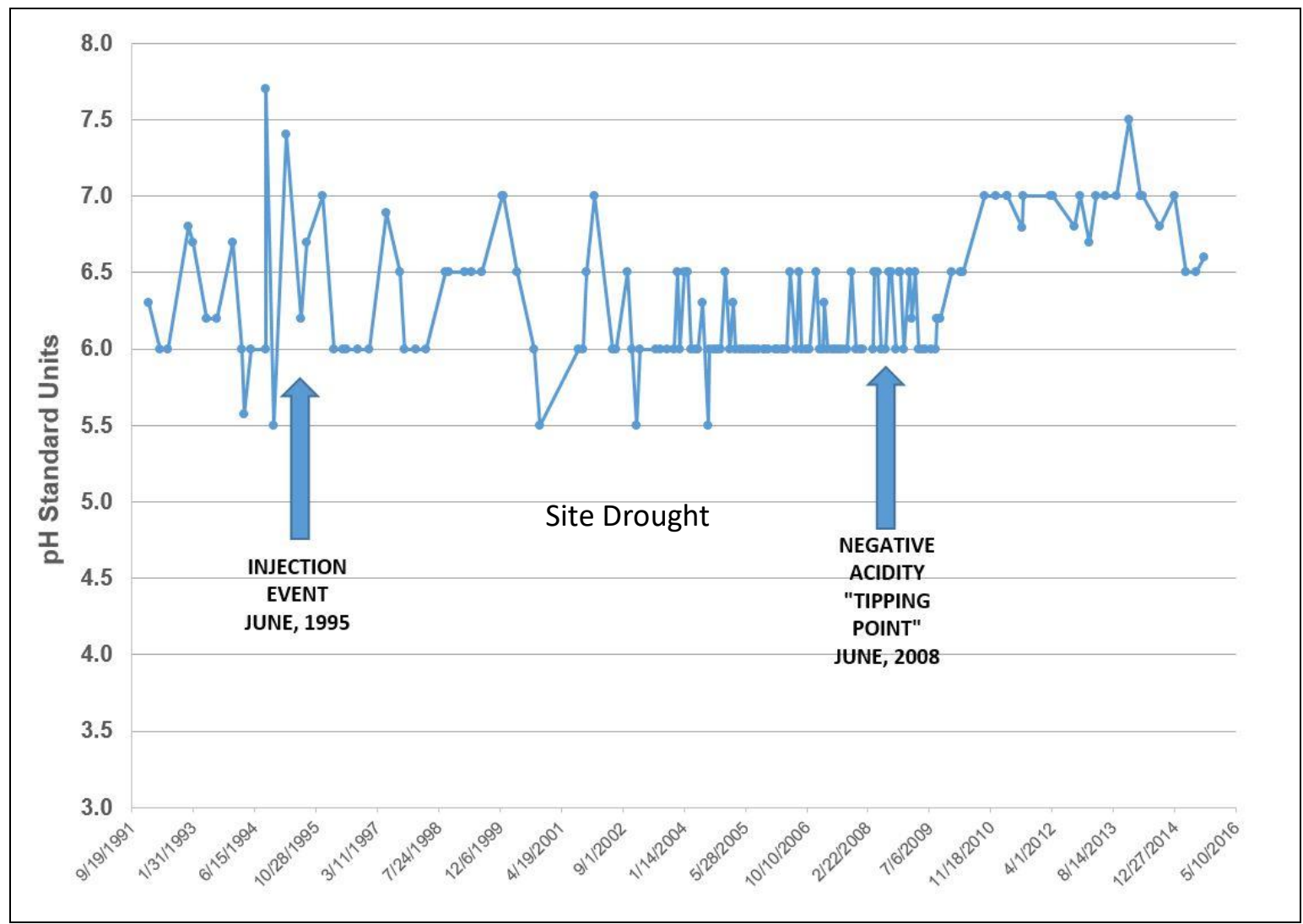

Figure 6. Seep pH 1991 to 2015.

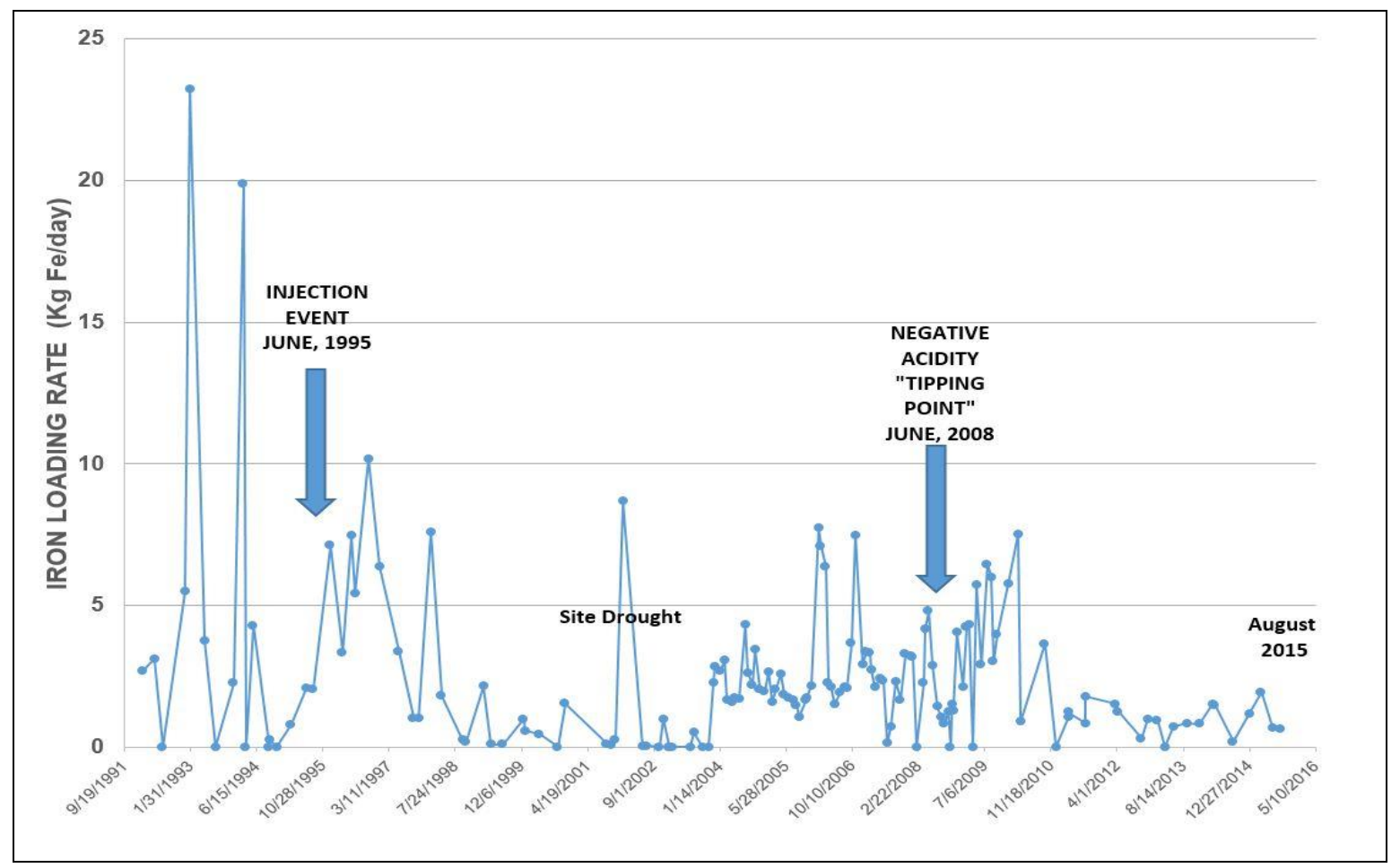

Figure 7. Seep iron loading 1991 to 2015. 
JASMR, 2016 Volume 5 Issue 1

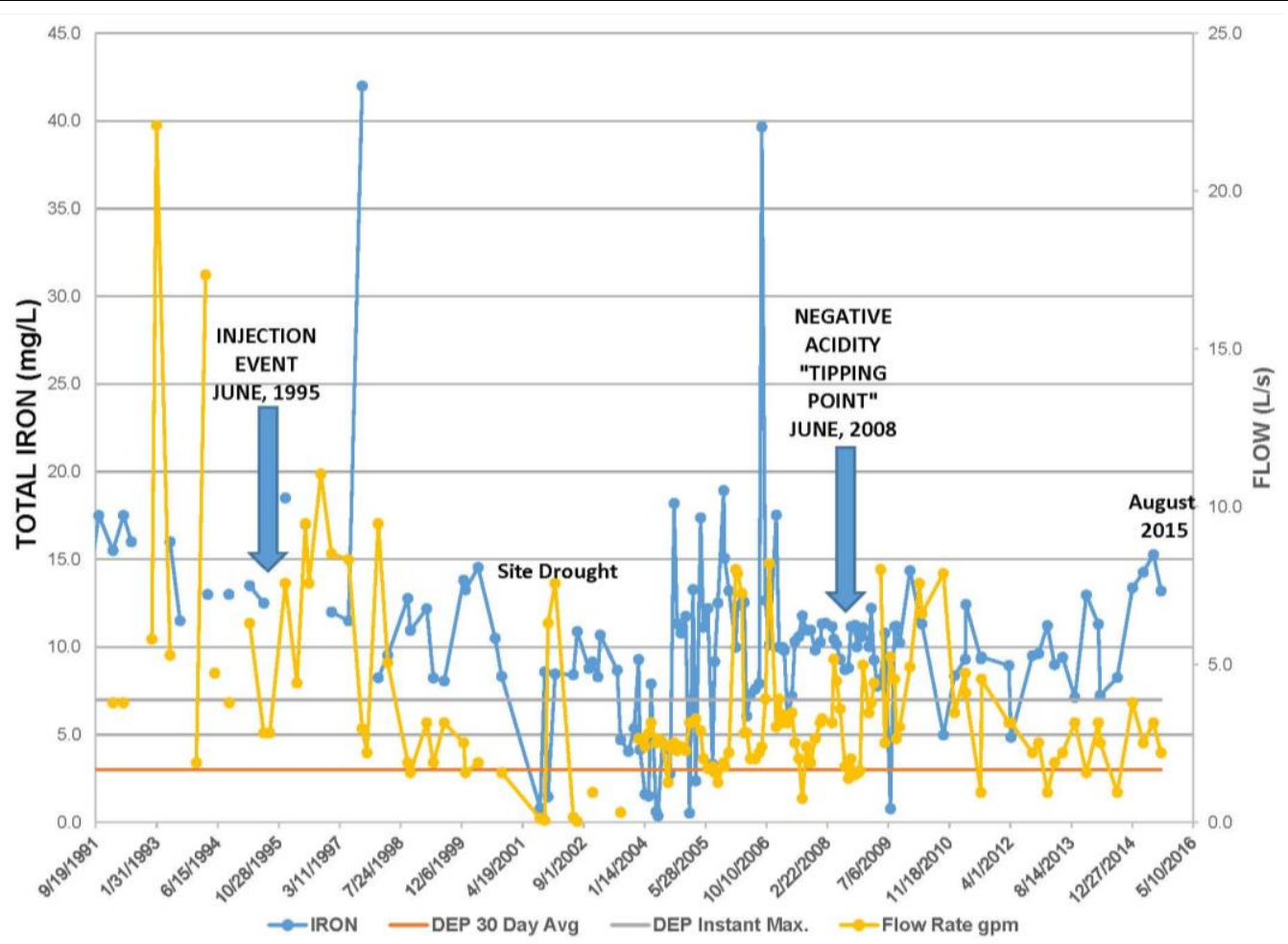

Figure 8. Seep iron concentration trend 1991 to 2015.

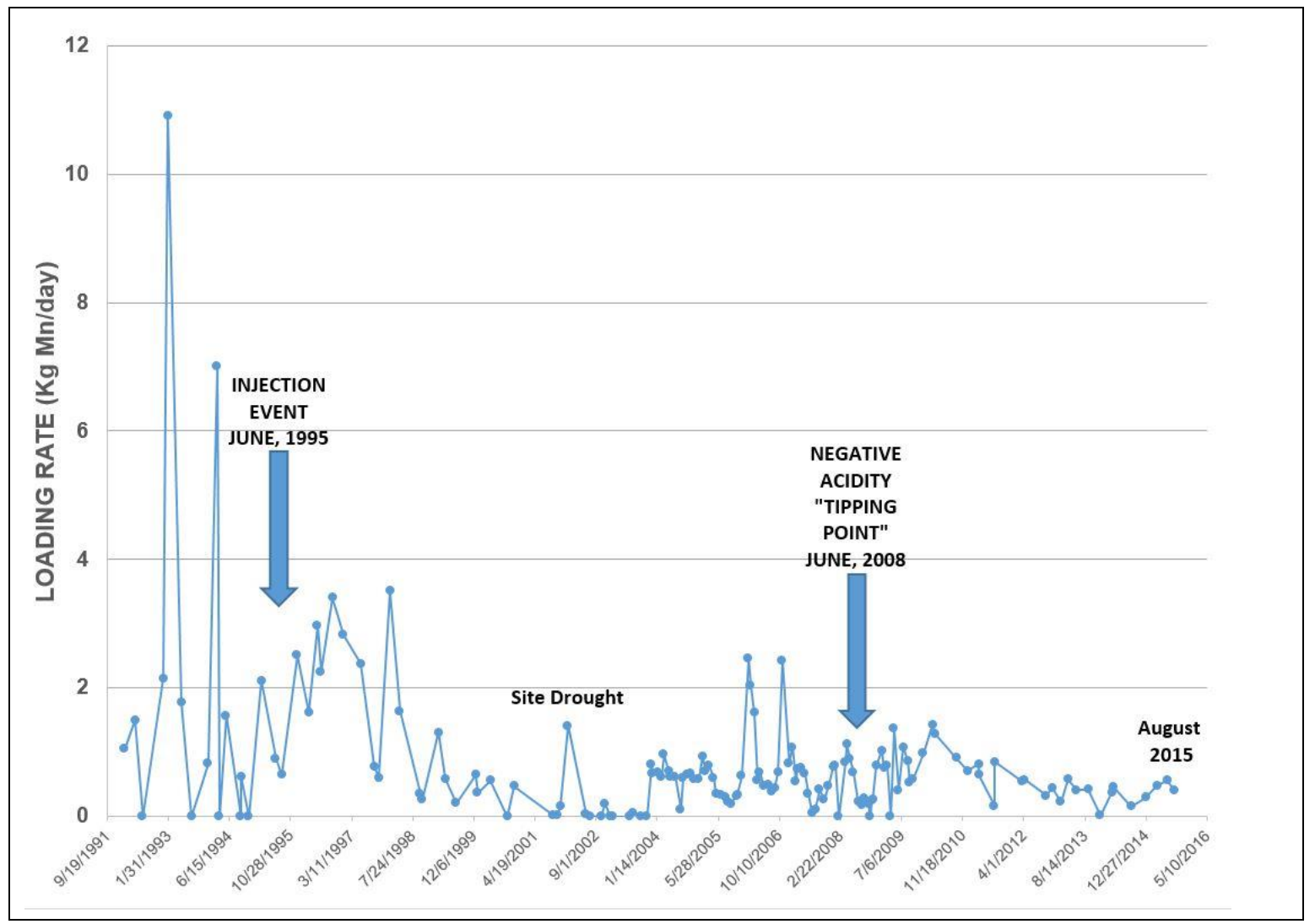

Figure 9. Seep manganese loading 1991 to 2015. 
JASMR, 2016 Volume 5 Issue 1

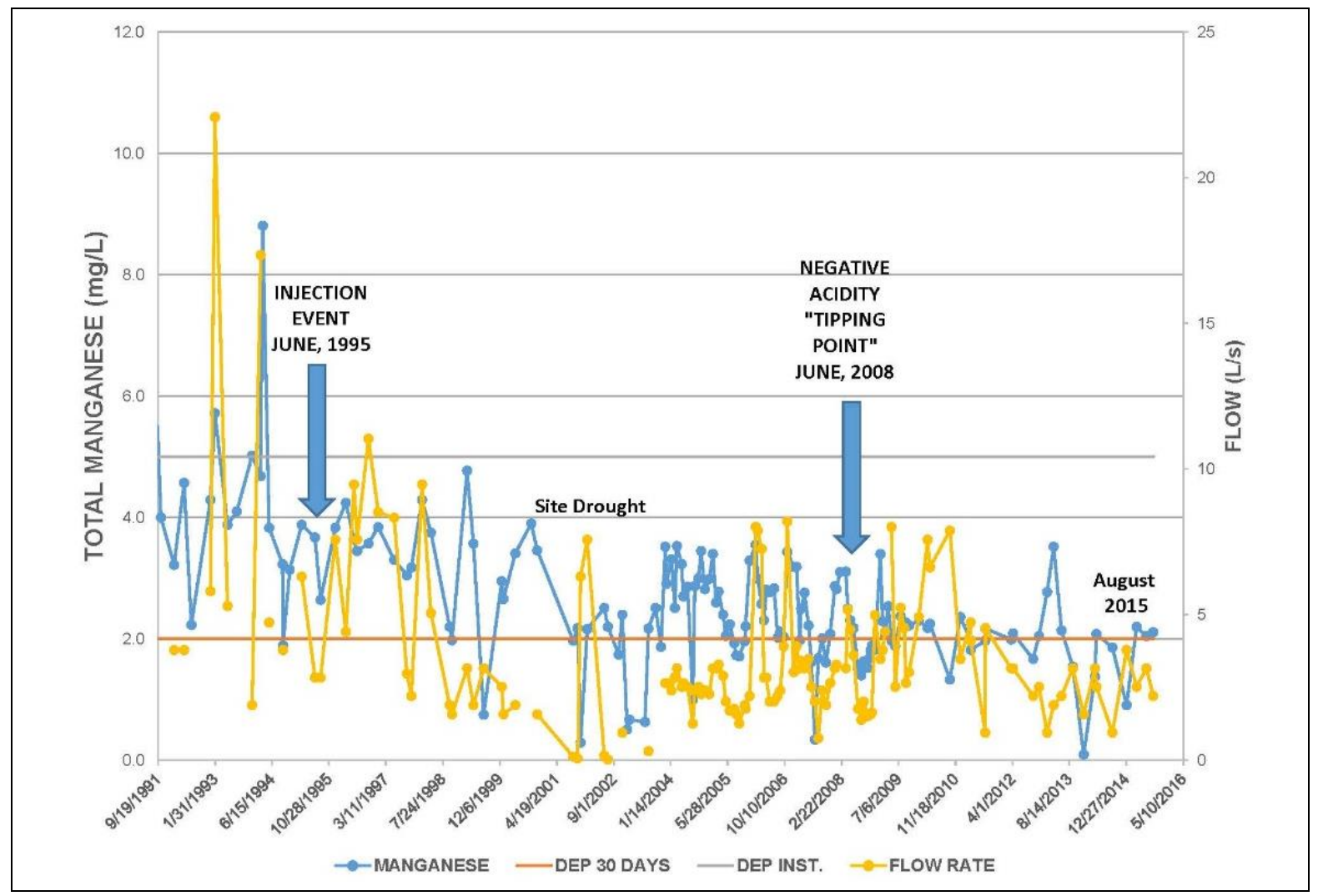

Figure 10. Seep manganese concentration trend 1991 to 2015.

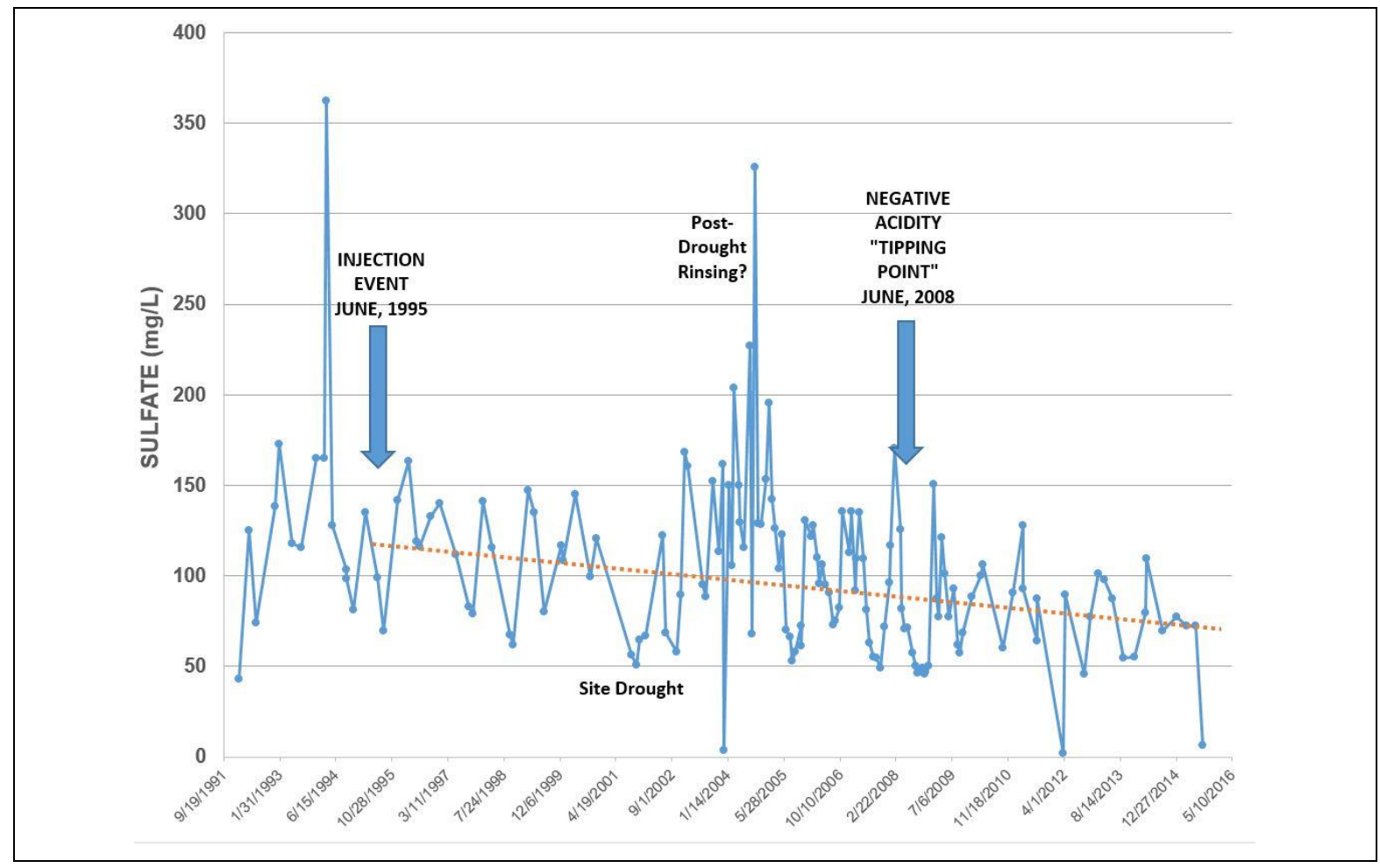

Figure 11. Seep sulfate concentration trend 1991 to 2015. 


\section{Discussion}

Almost Complete Sterilization?

Granted, the chemistry of Fisher Mine MIW was not as "aggressive" as acid rock drainage from more challenging mining sites that are too numerous to name. However, the data presented in Figs. 4 through 11 suggest that the positive effects of a single anti-bacterial application/injection event might persist for at least two decades. These observations are encouraging. The acidity/alkalinity "tipping point" is worthy of additional discussion. Unpublished laboratory data (Clark, 2013) suggests that the concentrations of sodium lauryl sulfate in the injected solution used at the Fisher Site would have certainly decimated the acidophilic community. However, it also probably decimated the isolated populations of beneficial heterotrophic bacteria as well, leaving the treated zone in an almost sterile condition. Without supplementary inoculation with heterotrophic bacterial consortium, total site recovery may have been delayed. Alternative staggered dosing strategies may be beneficial.

\section{Negative Acidity Tipping Point}

Kirby and Cravotta (2005) discussed hot acidity testing protocol and found that the presence of $\mathrm{Fe}^{+2}$ may result in negative acidity values; the oxidation with $\mathrm{H}_{2} \mathrm{O}_{2}$ could force $\mathrm{Fe}^{+2}$ to $\mathrm{Fe}^{+3}$, which consumes $\mathrm{H}^{+}$ions (see equation 1 below), raising the $\mathrm{pH}$. This reaction step occurs prior to the hydrolysis of $\mathrm{Fe}^{+3}$ (equation 2) which would depress the $\mathrm{pH}$. Unfortunately, iron speciation, dissolved oxygen, or oxidation reduction potential (ORP) data for the Fisher seep is non-existent.

(1) $\mathrm{Fe}^{+2}+\mathrm{H}^{+} \rightarrow \mathrm{Fe}^{+3}$ ( $\mathrm{pH}$ rises)

(2) $\mathrm{Fe}^{+3}+3 \mathrm{H}_{2} \mathrm{O} \rightarrow \mathrm{Fe}(\mathrm{OH})_{3}+3 \mathrm{H}^{+}(\mathrm{pH}$ falls $)$

There may be other explanations for the negative acidity tipping point, i.e., reporting changes. But if the ratio of acidophilic to heterotrophic bacteria counts was about equal, one might expect $\mathrm{Fe}^{+3}$ to predominate the seep discharge chemistry. However, if the heterotrophic populations finally grew to outnumber the acidophiles as observed 10 years post-treatment by Sobek et al. (1990) at the Route 43 site in Ohio, one might expect to observe $\mathrm{Fe}^{+2}$ (and the associated negative acidity values) in the effluent samples. Whether this could occur in as short a time span as suggested in Fig. 4 is uncertain and is worthy of additional study. However, it appears to be a persistent condition for the past seven years. Future research work at the site (or elsewhere) might focus on better understanding this phenomenon. 


\section{$\underline{\text { Sulfate Trends Compared to Other Parameters }}$}

It is interesting that the sulfate levels decreased slowly, whereas acidity, $\mathrm{pH}, \mathrm{Fe}$, and Mn levels decreased abruptly in response to the injection event. Residual gypsum or sulfate salts from 11 years of unsuppressed pre-injection pyrite oxidation (which would be slow to rinse) may account for a portion of this lag in sulfate response. Other microbial-related mechanisms could have also contributed. The data observed through the prolonged drought in about 2001 and thereafter may be worthy of a closer examination. The authors are willing to share the available data with qualified researchers.

\section{Hypothetical Effects of a Healthy Vegetative Cover}

As previously discussed, the ARD inhibitory effects of organic acids derived from site vegetation cited by Sobek et al. (1990) appears to be an important component in the long term (i.e., greater than three years) success of anionic surfactant usage. In hindsight, the currently-observed geochemical benefits in the seepage might have occurred sooner if increased attention had been paid to a more-rapid maturation of the vegetative cover at the Fisher Site. However, the prolonged drought conditions in the decade following the injection event would have certainly complicated these efforts had they been implemented. The role of vegetation in preserving an acidophilic "sterilized" sulfide waste condition is a worthy research topic.

Regardless, successfully implementing this technological strategy at other sites should consider design measures that sustainably accelerate vegetation success.

\section{Conclusions}

The Fisher Site subsurface injection project was the first time that a combination of geophysical mapping and well injection of alkaline materials followed by efforts to inhibit bacterial production had been used to mitigate acid seeps from a reclaimed mine site. Two decades of data suggest that the beneficial effects of the method appear to be permanent and may improve even more in the future. Granted, the Fisher Site may not have presented an "extreme" biogeochemical challenge; there is also the possibility that the readily leachable pyrite in the backfill was depleted over time. However, one must start somewhere and this technology (coupled with a better understanding of the biogeochemistry of a given site) may offer a permanent remedy to ameliorate discharge problems leading to protection of groundwater resources, eliminate 
permanent surface treatment facilities, and ultimately allow the release of mine reclamation bonds on revegetated mine sites currently experiencing ARD problems.

\section{$\underline{\text { Literature Cited }}$}

Bayona, M.R., F. Nocete, Nuno Inacio, J.M. Niteo, R. Saenz, J. Delgado, and A. Peramo. 2013. Environmental Effects and Impact of Mining-Metallurgical Activities in the Prehistory of the Iberian Peninsula: Contributions and New Data from the Scope of the Portuguese Empirical Universe. CPAG 22, 2012, 231-253.

BMR. 1984. Surface Mining Permit. Common Wealth of Pennsylvania Department of Environmental Resources Bureau of Mining and Reclamation.

Caruccio, F. and G. Geidel. 1986. Reclamation Strategies as Applied at the DLM Properties. West Virginia Mine Drainage Task Force.

Clark, T. 2013. Personal. Comm.

Jin, S., P.H. Fallgren, J.M. Morris, and J.S. Cooper. 2008. Source Treatment of Acid Mine Drainage at a Backfilled Coal Mine Using Remote Sensing and Biogeochemistry. Water Air Soil Pollution 188:205-212. http://dx.doi.org/10.1007/s11270-007-9536-4.

Kirby, C.S. and C.A. Cravotta, III. 2005. Net alkalinity and net acidity 2: Practical considerations, $\begin{array}{llll}\text { Applied } & \text { Geochemistry } & 20 & \text { (2005) }\end{array}$ http://dx.doi.org/10.1016/j.apgeochem.2005.07.003.

Kleinmann, R. L. P., D. A. Crerar, and R. R. Pacelli. The Biogeochemistry of Acid Mine Drainage and a Method to Control Acid Mine Drainage. Mining Engineering, v. 33, 1980, pp. 300-306.

Kleinmann, R.L.P. 1979. Biogeochemistry of acid mine drainage and a method to control acid formation. Ph.D. Thesis, Princeton University, Princeton, N.J. 104 pp.

Kleinmann, R.L.P. and P.M. Erickson. 1983. Control of acid drainage from coal refuse using anionic surfactants. Bureau of Mines RI 8847, 16 pp.

Lundgren, Donald. 1971. Inorganic Sulfur Oxidation by Iron-Oxidizing Bacteria. USEPA Water Pollution Control Research Series \#14010 DAY 06/71.

National Center of Biotechnology Information (NCBI). Gold Mining's Dirty Secret. http://www.ncbi.nlm.nih.gov/pmc/articles/PMC1242089/pdf/ehp0109-a00474.pdf 18 Apr 16. 
Pichtel, J.R. and W.A. Dick. 1991. Influence of Biological Inhibitors on the Oxidation of Pyritic Mine Spoil. Soil Biology and Biochemistry, Vol 23, No. 2, 1991, pp 109-116. http://dx.doi.org/10.1016/0038-0717(91)90121-Y.

Plocus, V. G. and V. Rastogi. 1997. Geophysical Mapping and Subsurface Injection for Treatment of Post-Reclamation Acid Drainage. Proceedings American Society of Mining and Reclamation, 1997. pp 34-42 https://doi.org/10.21000/JASMR97010034.

Rastogi, V. 1996. "Water quality and reclamation management in mining using bactericides," Mining Engineering. pp. 71-76 April 1996.

Robertson, A. McGregor and J. P. Barton-Bridges. (no date). Management Options for the Shortand Long Term Control of Acid Mine Drainage. pp. 156-176. Downloaded from (https://www.rgc.ca/files/publications/mgn_options_amd.pdf 3 March 2016.

Schrenk, M.O., K.J. Edwards, R.M. Goodman, R.J. Hamers, and J.F. Banfield. 1998. Distribution of thiobacillus ferrooxidans and leptospirillum ferrooxidans: implications for generation of acid $\begin{array}{lll}\text { mine } & \text { drainage. } & \text { Science }\end{array}$ http://dx.doi.org/10.1126/science.279.5356.1519.

Seyler, J., L. Figueroa, D. Ahmann, T.R. Wildeman, and M. Robustelli. 2003. "Effect of Solid Phase Organic Substrate Characteristics on Sulfate Reducer Activity and Metal Removal in Passive Mine Drainage Treatment Systems" Proceedings America Society of Mining and Reclamation, 2003 pp. 1112-1130 https://doi.org/10.21000/JASMR03011112.

Sobek, A.A., D.A. Beneditti, and V. Rastogi. 1990. Successful reclamation using controlled release bactericides: Two case studies, Proceedings American Society of Mining and Reclamation1990 pp. 33-41 https://doi.org/10.21000/JASMR90010033.

Tuttle, J.H., P.R. Dugan, and W.A. Apel. 1977. Leakage of cellular material from Thiobacillus ferrooxidans in the presence of organic acids. Applied and Environmental Microbiology 33:459-469.

Verburg, R., B. Johnson, M. Fordham, and M. Logsdon. 2003. A Rapid and Cost-Effective Method for Bench Screening of Geochemical Performance and Disposal Options for High-Sulfide Tailings. Presented at the $6^{\text {th }}$ International Conference of Acid Rock Drainage (ICARD), Cairns, QLD, Australia, July 12-18, 2003. pp 739-749. 